\title{
Speaking English With Preschoolers: Using Language to Further Children's Development
}

\section{Miriam T. Black}

Toyo Eiwa University

\section{Reference Data}

Black, M. (2021). Speaking English with preschoolers: Using language to further children's development. In P. Clements, R. Derrah, \& P. Ferguson (Eds.), Communities of teachers \& learners. JALT. https://doi.org/10.37546/JALTPCP2020-14

Language is not only a tool for communication, but it is also a framework for mental activity. Increased use of language in specific ways with preschoolers can guide them to develop new mental skills such as planning steps for taking action, imagining the future, and remembering details of past events. This article suggests that adults, even those whose first language is not English, can further the development of preschoolers. To that end, it first offers an overview of the importance of language development and explains how it is holistically integrated into learning activities in preschools. Next, the article details techniques early childhood educators (ECEs) and other adults can use to further children's mental development and introduces activities incorporating these techniques, when engaging preschoolers in speaking English. Finally, it introduces the author's classroom experience in the practical training of future ECEs as part of a Japanese university's English language program.

言語はコミュニケーションの道具だけではなく、精神活動の枠組みでもある。就学児童に特定の手法で言語使用を増や すことで、行動の手順を計画したり、先のことを想像したり、または過去の出来事の詳細を思い出したり、といった新しい精神 すことで、行動の手順を計画したり、先のことを想像したり、または過去の出来事の詳細を思い出したり、といつた新しい精神 スキルの発達へと導いていくことができる。本論文では、英語を第一言語としない成人でも、未就学児童の発達を促進する己 とができることを提示した。その目的を達成するために、まず言語発達の重要性を概観し、幼稚園での学習活動にそれがゼの 統合的に組み込なれているのかを說明した。次に、幼児教育者やその他の成人が児童の精神発達を促進するために使 えるテクーツクと、未就学児童に英語を話すよう仕问けるため、それらのテクニックを取り入れた活動を紹介した。最後に、日 本の大学の英語プログラムの一環として、筆者が教室で行った将来の幼児教育者育成のための実践的なトレーニングを紹介 する。 hat do children need for the healthy growth of their minds and bodies? Although perhaps not immediately obvious, a child's ability to use language skillfully, whether spoken or signed, is essential for their development. I came to this realization when, as an English teacher and a member of the Department of Early Childhood Education and Care at a Japanese university, I studied theories of child development, with a special focus on language development. Initially, I was drawn to the importance of language in a child's development through the work of Alexander Luria (1902-1977), a neuropsychologist who was a colleague of Lev Vygotsky.

Luria produced much experimental evidence supporting and expanding Vygotsky's theories of child development (Luria, 1979/1982; Luria \& Yudovich, 1957/1971; Vygotsky \& Luria, 1930/1993). From the body of Luria's research and that of others, notably Bodrova and Leong $(2001,2007)$, who extended Luria's findings with preschool-aged children ( 3 to 5 years old), it can be seen that early childhood educators (ECEs) and other adults are able to use language and verbal exchange to influence the development of children's thinking skills and overall development. Therefore, being able to speak effectively with children is of utmost importance for not only an ECE, but also for parents, caregivers, and second language teachers, regardless of the target language used.

This paper offers that ECEs, even those whose first language is not English, can further the language development of preschoolers. It first identifies some general stages in a preschooler's first language development. Next, drawing from Luria's work and that of Bodrova and Leong (2007) in particular, it outlines several techniques that can be universally applied to further the mental development of preschoolers, including activities that incorporate these techniques when engaging young children in speaking English.

Finally, the article details an in-class practical experience of training future ECEs to use these techniques in the activities with their peers as part of an English language program at a Japanese university. The aim was to better understand the scaffolding needed to help ECEs whose first language is not English speak effectively with preschoolers. In particular, specific challenges are identified for those who are preparing 
to become Japanese childcare center (hoikuen) workers and preschool (youchien) teachers. Direction for a more in-depth future investigation arose from this.

\section{Holistic Language Development}

In many parts of the world today, official early learning frameworks and guidelines explain young children's language development as an integrated part of a holistic practice. Spoken language by ECEs that encourages verbal exchange with children is integrated into almost every activity (Atkinson, 2019; Tobin, Hsueh, \& Karasawa, 2009). This is because language ability emerges initially through shared interaction involving spoken or signed language between the infant and others. As Bodrova and Leong (2007) write, "Between 3 and 6 months of age, babies begin to use smiles and vocalizations to invite the caregivers to engage in emotional exchanges" (p. 102). In other words, it is the infants who are initiating the exchanges. As toddlers begin to make purposeful gestures, such as reaching for a toy, the adult will assign meaning to the movement, perhaps saying something such as "You want this toy, don't you?" or holding up two things and asking which one the child would like. Thus, the child develops independence and control of the surrounding environment by their gestures and vocalizations.

The first words children say are also initially given meaning by adults, and thus, speaking is reinforced. For example, a toddler might say, "Da, da," and point when a dog is nearby. The adult might then smile and respond saying something such as "Yes, that's a dog. Let's go see the doggie." Of course, toddlers understand little of the exact dictionary meanings of these spoken words at first, but the adult's voice involuntarily causes them to attend more closely to elements in the immediate context (Luria \& Yudovich, 1957/1971). Furthermore, the tone of voice, facial expression, and gestures of the speaker along with the words will become associated with the experience of meeting the dog. In sum, the child's attention has been caught, a satisfying exchange has happened, and it is likely the child will vocalize more in the future because of it. Therefore, the basic, necessary requirements for children's language development are rather simple. Young children learn to use language when the following conditions are met: (a) they hear language spoken (or signed) in a situation to which they are attending and in which the meaning is clear or the words have some significance, and (b) their own spoken (or signed) utterances are encouraged and reinforced (Black, 2015).

Children aged 3 to 5 years old are still in the process of learning to speak their mother tongue with greater effectiveness and complexity, and adults are potential language teachers who can help them in this endeavor. In fact, ECEs do often consciously prepare target phrases in advance for use with preschoolers (Bodrova \& Leong, 2007). However, the specific words and phrases that are actually used will depend on how the children react to the situation and their verbal responses. Therefore, ECEs and other adult caregivers need to be flexible in their language use, adjusting it to the children. Subsequently, these holistic "language lessons" tend to be more open-ended and spontaneous when compared to what people might imagine typical language lessons to be.

It is useful to describe the stages in preschoolers' language development according to the context and purposes of their language use, rather than the amount of language or the grammar structures used. For example, there is some evidence that 14 English grammatical morphemes are acquired by toddlers in a certain order, but the rate of acquisition and the exact age at which each child acquires them varies and depends on many factors (Lightbown \& Spada, 2006). This information does not give the adult much insight as to what the child can and cannot do with their language ability or the assistance the child might need. However, most children at a certain stage of development are observed to be talking to themselves, narrating their actions in individual play activities, or giving themselves reminders to be careful about the movements they are making. Vygotsky called this private speech, as it is not intended for communication with others, but yet it is a commonly observed stage in child development and plays a role in the advancement of thinking skills (Black, 2010; Bodrova \& Leong, 2007). Awareness of these stages of language development can help ECEs to better determine the kind of intervention that will move each child forward in learning.

In general, the younger the children are, the more attention they pay to what they are sensing in their immediate situation rather than the words that they are simultaneously hearing (Luria, 1979/1982). Therefore, preschoolers' language development can be seen along a continuum that begins with verbalizations about aspects of their immediate situation. Then, with more fluency, their actions and words begin to include what they are not experiencing at the moment, for instance when retelling past events or asking questions. A similar continuum is true of preschoolers in second language interactions: Their first meaningful utterances will arise out of communication with sensitive speakers about what is happening at the moment.

\section{Techniques for Using Language to Further a Child's Menta Development}

With this holistic view of language development in mind, this section introduces some basic teaching techniques effective in furthering both a preschooler's language 
development and mental development. All three of these demonstrate efficacy and are universally applicable. That is to say that they can be adapted for use in any culture and with any language and can be used with preschoolers at various stages of development.

\section{Pointing Out, Naming, and Describing}

Luria and Yudovich (1957/1971) explain in detail the neuropsychological effects that the simple act of pointing at something and naming it has on a child's perception. In short, this action draws the child's attention to an item or a specific feature of it, thus making it stand out from the field of other sensory impressions they are receiving at the same moment. Because of the child's enhanced attention, what is pointed out is more likely to be remembered. By pointing something out, the ECE can direct attention to key features of objects that children might not have noticed on their own or help the child to deliberately "ignore competing or distracting information and to focus on specific characteristics that are important to solving a problem or learning a task" (Bodrova \& Leong, 2007, p. 55). Furthermore, by identifying key features of classes of objects, such as books, children are able to begin to generalize and use this abstract information to identify other objects they encounter in the future as "books" (see also Black, 2010, 2018a).

\section{Making Connections}

When asked about their earliest recollections as children, people will not usually be able to remember much specifically before the age of around two, and if so, these memories primarily involve sensory impressions. This is related in part to the fact that the language-related thinking skills necessary for creating detailed memories are only beginning to develop. Language allows people to more readily recall details of past experiences and imagine the future. Verbally recalling the past can help children understand new situations, predict more accurately what will happen, and take more effective action.

Bodrova and Leong (2007) also make a distinction between what they call the associative memory, which is increased by repetition, and the deliberate memory in which language helps to categorize new information and connect it with what is already known. For example, they explain that 2-year-olds have difficulty answering when only given colored cards and asked which one is red and which is orange. However, when shown a card and asked whether it is the color of a tomato or an orange, a greater number of correct answers are elicited. Therefore, the ECE should not only talk with the child about what is happening at the moment, but should also begin to gradually connect the immediate context with the child's past experiences or with objects that are not in present view.

\section{Making Guesses and Predictions}

When children's language ability increases, so does their ability to think abstractly (Luria, 1979/1982). They are no longer bound to the immediate situation but can draw from memories of past experiences and apply previous knowledge to new situations. The ability to predict what will happen next or how something will behave based on previous experience is one example of this. When children vocalize thoughts, vague ideas can gain clarity and become available to the surrounding people for discussion. ECEs can listen to children, help them to make and test predictions, and guide them to discover more precise answers to their questions.

\section{Activities to Engage Preschoolers' Minds Through Speech}

This section introduces some activities through which the techniques described above can be implemented. Selection criteria for the activities were the following: (a) they do not need much preparation in terms of time and materials, and (b) they can be adapted to the educational culture in which they are used. For example, preliminary activities involving reading and writing are introduced in preschools at different stages and in various ways across the world (Hayashi \& Tobin, 2015; Tobin, Hsueh, \& Karasawa, 2009). However, all children first develop a degree of fluency in speaking their mother tongue before they learn to read and write. For this reason, the activities selected here involve primarily verbal exchange (spoken or signed), although written language could be incorporated into them if appropriate.

\section{Interacting With Children While Reading a Picture Book}

The language development benefits of reading aloud to children are not limited to those that arise merely from reading the text of the book (Bodrova \& Leong, 2007; May, 2011). For example, the illustrations in children's picture books can sometimes contain even more detailed information than the text provides as in the book Good Night, Gorilla (Rathmann, 1994). It is only by carefully viewing the illustrations that the essential points of the story can be discovered. With such books, the ECE can point out details of the illustrations, ask children to find specific details themselves, connect elements of the story with past experiences, and have children predict what they think will happen next. 
Another example of a book that can be used in this way is Little Daruma and Little Tengu, A Japanese Children's Tale (Kako, 1967/2002). In this story, the main character Little Daruma, admires things that his friend Little Tengu has. For example, first he wants a fan like Little Tengu's and asks his father for one. Daddy Daruma collects all the fans in the house and shows them to Little Daruma. However, Little Daruma is not satisfied with any of them. Finally, he spies the leaf of a plant through a window and uses that for his new fan.

The same thing happens when searching for a hat, shoes, and other objects. Each time that Daddy Daruma brings him a collection of items from which to choose, Little Daruma always chooses something unexpected. Thus, this book provides many chances for the ECE to point out features of various objects to connect the story and illustrations to experiences and objects in the child's life. Furthermore, children can be encouraged to predict the items Little Daruma will choose.

\section{See, I Think, I Wonder}

This activity was first introduced to me by a former colleague and is adapted from the See, Think, Wonder thinking routine which was developed by Project Zero, a research center at the Harvard Graduate School of Education (2019). Variations may be used, such as one that involves all the senses: sight, sound, smell, taste, and touch. In this activity, a photograph, a drawing, a scene set up with objects or toys, or an outdoor area is selected and shown to the children. Then, the ECE asks these three questions one by one: "What do you see?", "What do you think?", and "What do you wonder?" Each question can be represented by a drawing of an eye, a light bulb, and a question mark, respectively. The ECE solicits answers from various children and provides comments or questions them further about their answers.

In answering the question "What do you see?", children are encouraged to observe and point out details. The ECE can help with naming the items if the children's vocabulary is inadequate. The second and third questions are more challenging to answer because the children must be able to connect what is in front of them at the moment with other ideas or experiences in their heads. In answering these questions, they must also make statements including guesses and predictions. Instead of trying to explain what the words "think" and "wonder" mean, ECEs can give examples of answers, linking what they know the children already understand with new ideas and questions.

\section{Sink or Float?}

This activity is often used in preschools and one for which many online videos and books for children are available. The ECE arranges a clear glass bowl filled with water and a dozen or so small objects are placed next to it on a table. The objects include those both familiar and unfamiliar to the children and ones made of various materials that will sink or float. The ECE asks the children to choose an object and name it if they can. Then, the ECE verbally defines "sink" and "float," demonstrating each with two of the remaining objects at hand. The children are all asked to predict whether they think their chosen object will sink or float, and perhaps why they think that. The children then get chances in turn to see if they are correct by putting their objects in the water in the bowl. Objects that float can be taken out and put on one side of the bowl and those that sink on the other.

This activity can be extended in various ways depending on the developmental and language levels of the children. For example, a discussion involving pointing out the different materials that the objects are made of can be added. Or children may be encouraged to draw on information from past experiences in considering the reasons why some objects float and others do not. Children can also record the results on a chart for later reference.

\section{LEAP BC ${ }^{\mathrm{TM}}$ Hop Activity Card Set}

This 10-card set of activities is one set of resources created by Decoda Literacy Solutions (2017), a nonprofit organization based in British Columbia, Canada. Each card describes several activities centered around a theme. The activities include games involving physical activity and children's picture books, songs, rhymes, and poems. There are tips on how to conduct the games smoothly and variations of the games are recommended for the inclusive classroom. Suggested phrases are also given for the adult to use when pointing out important details and asking children questions during the course of the activities. With the help of verbal guidance and comments from ECEs, children are encouraged to take creative action, talk about what they are doing and have done, and add new information to the theme.

Training Japanese University ECE Students to Use the Activities

The following section explains the author's in-class practical experience of teaching ECE majors in a Japanese university to use the above techniques and activities with peers. 
Since even people whose language skills are not perfect can learn to be effective language facilitators, the aim was to discover what special assistance ECEs whose first language is not English might need to implement the activities.

As the person responsible for the development of an ECE department's required English classes, I created a content and language integrated learning (CLIL) curriculum in 2017. This curriculum includes activities intended to increase the university students' English ability and further their knowledge and skills in the field of early childhood education (Black, 2018b). Since then, additional activities have been developed to strengthen the curriculum. In addition, the implementation of these techniques and activities by ECEs in a Japanese context moves to address a lack of materials that introduce English in a holistic way in Japanese preschools. This gap remains despite recent publication of teaching materials specifically designed for Japanese ECEs who desire or need to use English with children in their classrooms (see Miyata \& Takahashi, 2014, for example).

The goal is for university students to be able to use these activities in English with preschoolers. As English is an additional language for the ECE majors, much scaffolding is needed for them to be successful when trying the activities with peers. This is especially true for those with lower-level speaking skills. Two areas of challenge for students that arose from this experience and the scaffolding used to address them are described below.

\section{Using One's Whole Body and Voice to Make Meaning}

The spoken word is only one element that helps the child make meaning of a situation. The ECE's gestures and facial expression also aid understanding. Tone of voice, and its volume too, play a role in conveying intent. Therefore, an ECE's ability to speak in a way that increases children's understanding by using their whole bodies and voices is important.

In general, when implementing the activities with peers, at first the university ECE students' voices were flat and facial expressions unvaried. To address this, I had them practice reading children's picture books aloud after hearing a model. Many websites where children's books are read online were used for this. Audio and video files of selected materials and children's songs were also created for them, which they accessed for extra practice. Some improvement in the ECE students' use of voice and facial expressions were seen after such practice.

\section{Spontaneity and Accuracy of Language Use}

ECEs are models of language use for preschoolers. Therefore, speaking in simple English sentences with correct grammar is especially important for ECEs whose first language is not English. Using increasingly more complex structures and vocabulary with children is also key. Giving children more precise words to express their incomplete ideas and being explicit in directions or descriptions can further help to expand preschooler's language use. For example, instead of saying, "We measure something like this," one can say, "When we want to see how long something is, we put the ruler at the end of it and read the number here," while measuring with a ruler (Bodrova \& Leong, 2007). Furthermore, being flexible and spontaneous in responding to the unpredictable utterances and actions of children is also necessary.

This was probably the most difficult aspect to master for the Japanese ECE majors. As English is not their mother tongue, they still make many basic grammar and pronunciation mistakes. To address this, some examples of "teacher talk" sentences (Appendix) were prepared to assist them. They also wrote short scripts to use when trying the activities. Initially, they were allowed to view these scripts when implementing the activities with their peers, but gradually they were encouraged to be more spontaneous. Although they did become more spontaneous, accuracy decreased as they moved away from their prepared sentences.

\section{Conclusion}

In this article, I have reiterated the importance of language development in children's early years and the significant role caregivers play in influencing this. Research indicates that adults, particularly ECEs, can take action to positively influence preschoolers' development when they speak and interact with them in targeted ways (Bodrova \& Leong, 2007; Luria \& Yudovich, 1957/1971). Therefore, some techniques and activities for this purpose were described.

In addition, even people whose language skills are not perfect can learn to be effective language facilitators. To discover more about this, the activities and techniques explained in this article were used in a preliminary trial with Japanese university ECE majors. This was to identify the scaffolding they needed to improve their speaking of English with preschoolers. Although they faced several specific challenges due to a lack of fluency, there is an indication that with assistance, they can become effective facilitators of children's development through the use of English. 
Though not a formal experiment, this in-class practical experience highlighted two directions for future investigation. First, in this trial, Japanese university ECE majors used the activities with peers, not preschoolers. Therefore, more investigation is needed for adapting the activities for use with preschoolers in the Japanese context. The second involves further investigation into additional scaffolding to use with ECEs with lower English skills so they can effectively implement the activities. Finally, investigation in this area is also essential as English language activities are now being introduced in elementary schools in Japan. It is crucial that those teachers, who may be imperfect speakers of English, are given the appropriate assistance to develop their speaking skills.

\section{Bio Data}

Miriam T. Black is an associate professor in the Department of Early Childhood Education and Care of the Faculty of Human Sciences at Toyo Eiwa University, Yokohama, Japan. Her areas of interest include examining the role of language in the development of higher thinking processes, especially in preschool-aged children and those with special needs. <mblack@toyoeiwa.ac.jp >

\section{References}

Atkinson, K. (2019). British Columbia early learning framework. British Columbia Ministry of Education. Retrieved from https://files.eric.ed.gov/fulltext/ED605504.pdf

Black, M. (2010). 子どもの言語習得と精神発達に与える大人の影響 [The adult's influence on young children's acquisition of language and the development of their mental processes] (M. Kasatani, Trans.). In Toyo Eiwa University Institute of Thanatology (Ed.), 死生学年報2010死生観を学ぶ [Annual of the Institute of Thanatology 2010, learning different views of death and life] (pp. 139-164). Lithon. Retrieved from http://id.nii.ac.jp/1093/00001361/

Black, M. (2015). The necessary conditions for first language learning part 1: A. R. Luria's investigation of twins. The Journal of the Graduate School of Toyo Eiwa University, 11, 11-22. Retrieved from http://id.nii.ac.jp/1093/00000461/

Black, M. (2018a). Speaking English with children: The benefits of the spoken word. Toyo Eiwa Journal of the Humanities and Social Sciences, 35, 51-64. Retrieved from http://id.nii. ac.jp/1093/00001387/

Black, M. (2018b). Moving toward CLIL for early childhood educators in a university. In P. Clements, A. Krause, \& P. Bennett (Eds.), Language teaching in a global age: Shaping the classroom, shaping the world. JALT. Retrieved from https://jalt-publications.org/articles/24381-movingtoward-clil-early-childhood-educators-university
Bodrova, E., \& Leong, D. (2001). Tools of the mind: A case study of implementing the Vygotskian approach in American early childhood and primary classrooms. Innodata Monographs 7. Retrieved from https://unesdoc.unesco.org/ark:/48223/pf0000124770?posInSet=1\&queryld=c5c $45 \mathrm{c} 87-\mathrm{a} 182-415 \mathrm{a}-8 \mathrm{c} 45$-fc5c0a9f85b0

Bodrova, E., \& Leong, D. (2007). Tools of the mind, the Vygotskian approach to early childhood education (2nd ed.). Prentice Hall.

Decoda Literacy Solutions. (2017). LEAP BC ${ }^{\mathrm{TM}}$ Hop activity card set. Retrieved from http://www. decoda.ca/resources/rsc-child-family/leap-resources/hop/hop-activity-card-set/

Hayashi, A., \& Tobin, J. (2015). Teaching embodied, cultural practice in Japanese preschools. University of Chicago Press.

Kako, S. (2002). Little Daruma and Little Tengu, a Japanese children's tale (P. Howlett \& R. McNamara, Trans.). Tuttle Publishing. (Original work published 1967)

Lightbown, P., \& Spada, N. (2006). How languages are learned (3rd ed.). Oxford University Press. Luria, A. R. (1982). Language and cognition (J. V. Wertsch, Trans.). John Wiley \& Sons. (Original work published 1979)

Luria, A. R., \& Yudovich, F. (1971). Speech and the development of mental processes in the child (O. Kovasc \& J. Simon, Trans.). Penguin Education, Penguin Books. (Original work published 1957)

May, P. (2011). Child development in practice, responsive teaching and learning from birth to five. Routledge.

Miyata, M., \& Takahashi, T. (2014). 保育英語の練習帳 [English for nursery teachers]. Houbunshorin. Project Zero. (2019). See, think, wonder. Harvard Graduate School of Education. Retrieved from https://pz.harvard.edu/resources/see-think-wonder

Rathmann, P. (1994). Good night, Gorilla. G. P. Putnam's Sons.

Tobin, J., Hsueh, Y., \& Karasawa, M. (2009). Preschool in three cultures revisited, China, Japan, and the United States. University of Chicago Press.

Vygotsky, L. S., \& Luria, A. R. (1993). Studies on the history of behavior, ape, primitive, and child (V. I. Golod \& J. E. Knox, Trans.). Lawrence Erlbaum. (Original work published 1930)

\section{Appendix}

Example Teacher Talk for Activities Interacting With Children While Viewing a Picture Book Together Pointing Out, Naming, and Describing

- "Look! There's a

"Do you see the here?" 


\section{JALT2020}

COMMUNITIES OF
TEACHERS \& IEARNERS

- "Hey, I see

"Who is that?"

- "What is that?"

Making Connections

- "I like

- "Do you like

- "I have a ?"

- "Do you have a

like the one here, too." ?"

"What is your favorite ?"

"Have you ever ?"

- "We yesterday, too. Do you remember?"

Making Guesses and Predictions

- "What do you think will happen next?"

- "What do you think (character's name) will do now?"

\section{See, I Think, I Wonder}

Pointing Out, Naming, and Describing

- "What do you see?"

- "Let me give you an example. I see

- "I see ____, too!"

- "I don't see it. Show me where it is."

- "Oh, now I see it!"

Making Connections, Guesses, and Predictions

- "What do you think?"

- "Let me give you an example. I think

- "I think

- "Yes, I think that, too."

- "Why do you think that?"

- "Oh, I understand now."

- "What do you wonder?"
Black: Speaking English With Preschoolers: Using Language to Further Children's Development

- "Let me give you an example. I wonder if

- "Let me give you an example. I wonder why

" "Yes, I wonder that, too."

- "Why do you wonder that?"

- "What thing in the picture made you wonder about that?"

Sink or Float?

Pointing Out, Naming, and Describing

- "Something sinks when you put it in water and it falls to the bottom like this."

- "Something floats when you put it in the water and it stays on top of the water like this."

- "What is this (adj.) thing?"

- "What is a (name of object) used for?

- "What is it made of?"

Making Guesses and Predictions

- "Do you think this (name of object) will sink or float if we put it in the water?"

- "Why do you think that?"

" "Let's try it." 